\section{Establishment of Calibration Curves for Comparing Pour-through and Saturated Media Extract Nutrient Values}

\author{
Todd J. Cavins, ${ }^{1}$ Brian E. Whipker, and William C. Fonteno \\ Department of Horticultural Science, North Carolina State University, Raleigh, \\ NC 27695-7609
}

Additional index words. bulk solution displacement, Euphorbia pulcherrima 'Freedom Red', poinsettia, pourthrough, SME, soil testing, substrate

\begin{abstract}
Most commercial and university substrate testing laboratories' recommended floriculture nutritional values are based on the saturated media extract (SME) method. With the recent gain in popularity of pour-through nutritional monitoring, alternative recommended values are needed for nutrient analyses based on pour-through extracts. Pour-through nutritional values were compared to the SME values to develop calibration curves and recommended nutritional values. Euphorbia pulcherrima 'Freedom Red'Willd.ex Klotzch. were grown for two consecutive growing seasons in $16.5 \mathrm{~cm}$ plastic pots with Fafard $4 \mathrm{P}$ root substrate and fertigated with 200,300 , or $400 \mathrm{mg} \cdot \mathrm{L}^{-1} \mathrm{~N}$ from a $13 \mathrm{~N}-0.88 \mathrm{P}-10.8 \mathrm{~K}$ fertilizer. Linear relationships existed and inverse calibration curves for pour-through and SME comparisons were developed for $\left(r^{2}\right)$ : $\mathrm{EC}(0.98), \mathrm{NO}_{3}^{-}(0.98), \mathrm{P}(0.97$ to 0.99$), \mathrm{K}(0.99)$, $\mathrm{Ca}(0.94$ to 0.97$)$, and $\mathrm{Mg}(0.91)$. In addition, recommended pour-through substrate value ranges were developed for comparison with SME values. The established calibration curves and pour-through substrate value ranges will allow substrate-testing laboratories to make nutritional recommendations based on pour-through extractions.
\end{abstract}

Pour-through was introduced as a quick and simple method to analyze potted-plant $\mathrm{pH}$ and electrical conductivity (EC) on-site (Wright, 1986; Wright et al., 1990; Yeager et al., 1983). Pour-through extraction occurs by the displacement of the bulk solution by distilled water poured over the top of a substrate as a means to obtain a nutrient sample. This method has been widely accepted by researchers and producers of woody ornamentals for approximately 20 years (Ruter, 1992; Wright, 1986; Yeager and Wright, 1981, 1982; Yeager et al., 1983). However, the greenhouse industry has been reluctant to accept this method until recent promotion at grower conferences and scientific meetings (D. Bailey, personal communication).

A possible reason for lack of acceptance may be that producers are already using a simple 2 water : 1 substrate (by volume) dilution slurry for on-site $\mathrm{pH}$ and EC testing. However, the 2:1 slurry does not generally provide a sample that is suitable for complete nutritional analysis due to the diluted nature of the substrate sample and inconvenience of shipping a slurry to a commercial or university laboratory. A pour-

Received for publication 12 Nov. 2003. Accepted for publication 9 Mar. 2004. This research was funded in part by the North Carolina Agricultural Research Service (NCARS). We would like to thank the Fred C. Gloeckner, Ohio Florist Foundation and the North Carolina Flower Growers' Association for grant support, Paul Ecke Ranch and Fowler's Nursery for providing plant material, Fafard Co. for providing substrate, and Scotts Co. for providing fertilizer. We thank Ingram $\mathrm{M}^{\mathrm{c}} \mathrm{Call}$ for production assistance. ${ }^{1}$ Former graduate research assistant and corresponding author. Currently assistant professor, Department of Horticulture and Landscape Architecture, Oklahoma State University, Stillwater, Okla. 74078-6027; e-mail cavinst@okstate.edu. applications. Calibration equations to compare the two testing methods directly were not provided. Similarly, Wright et al. (1990) presented correlations coefficients for pour-through or SME to tissue nutrient levels, but did not compare the two testing methods directly. While several researchers have validated pour-through as an interpretable substrate test, calibration equations to compare the two testing methods directly are still needed. Calibration equations would allow commercial or university laboratories to make recommendations based on pour-through extracts from established SME standard values.

Substrates used in floriculture production are commonly peatmoss or peatmoss and pinebark based (K. Santner, personal communication). Yeager et al. (1983) data were based on $100 \%$ pinebark substrate without plants. Although Wright (1986), reported no difference in nutrient extraction between a 1 peat : 1 perilite (by volume) and pine bark (100\%) substrate, nutrient retention may be differentially altered for each substrate by plant uptake. Lang and Elliot (1991) noted ammonium oxidation varied among soilless substrate types and that plants in the substrates affected oxidation. These considerations warranted additional investigation of pour-through.

Compton and Nelson (1997) noted that plants could drastically alter nutrient values in small substrate volumes and recommend testing 1 to $2 \mathrm{~h}$ after irrigation to obtain values representative of plant available nutrients. One to two hours allows for equilibration of the substrate solution. Standardized pour-through values based on conditions similar to those used by commercial floriculture producers that represent plant available nutrients are needed.

Wright et al. (1990) and Yeager et al. (1983) examined SME $\mathrm{pH}$ values obtained from the suctioned extract. Yet, Warncke (1998) suggest the $\mathrm{pH}$ samples should be obtained directly in the slurry. Values for $\mathrm{pH}$ obtained in the slurry may differ from $\mathrm{pH}$ values obtained in the vacuumed extract. The vacuum extraction can change the $\mathrm{CO}_{2}$ content of the solution, which may affect the $\mathrm{pH}$ (Lang, 1996; Van Leirop, 1990).

The objective of this study was to develop calibration curves of pour-through and SME nutrient values based on protocols used by commercial producers on containers with a common floriculture substrate and actively growing plants. Euphorbia pulcherrima 'Freedom Red' Willd. ex Klotzch. was chosen for this study as it is highest value potted flowering crop in the U.S. (U.S. Department of Agriculture, 2003). The values attained allow producers to use a single substrate solution extraction to achieve both on-site and complete nutritional analysis by a commercial or university laboratory. The calibration curves allow laboratories to develop standard pour-through nutrient values based on established SME standard values.

\section{Materials and Methods}

Hipp et al., 1979; Jarrell et al., 1979).

Yeager et al. (1983) provided correlation coefficients based on comparisons of pourthrough or SME extraction values to nitrogen, phosphorous, potassium, or dolomitic limestone
Euphorbia pulcherrima 'Freedom Red' Willd. ex Klotzch. rooted cuttings were transplanted on 15 Aug. into 16.5 -cm plastic pots (one plant per pot) using Fafard 4P commercial 
substrate (Fafard Inc., Agawam, Mass.) and fertigated with 200,300 , or $400 \mathrm{mg} \cdot \mathrm{L}^{-1} \mathrm{~N}$ from a $13 \mathrm{~N}-0.88 \mathrm{P}-10.8 \mathrm{~K}$ Cal-Mag fertilizer (Scotts Co., Marysville, Ohio). Polyethylene covered greenhouses were set at $21 / 16{ }^{\circ} \mathrm{C}$ (day/night) and the plants were grown under natural days. Substrate samples were collected at 6 and 9 weeks ( 0 representing transplanting of rooted cuttings). Pour-through extractions, modified from Wright (1986) were made $1 \mathrm{~h}$ after irrigation using $75 \mathrm{~mL}$ of distilled water to displace about $50 \mathrm{~mL}$ of leachate (Cavins et al., 2000;). Pour-through samples were tested for $\mathrm{pH}$ (Cole-Parmer lab $\mathrm{pH} / \mathrm{mv}$ meter $\pm 0.01 \mathrm{pH}$ units) and EC (Cole-Parmer lab
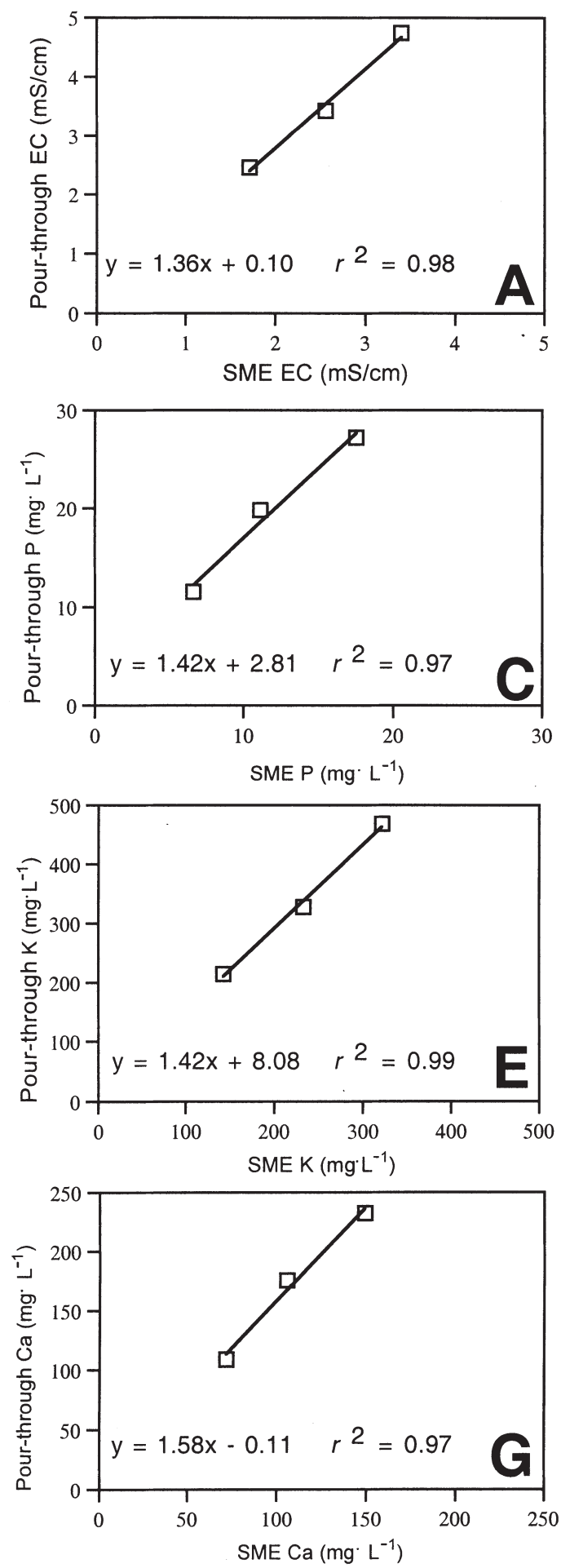

conductivity meter $\pm 0.01 \mathrm{mS} \cdot \mathrm{cm}^{-1}$ ) immediately following extraction. Substrate samples were selected at the same time for modified SME (Warncke, 1998). About $350 \mathrm{~cm}^{3}$ of substrate from the middle of the container was saturated with distilled water until glistening, then allowed to equilibrate for $30 \mathrm{~min}$ The $\mathrm{pH}$ was then measured in the slurry. After $\mathrm{pH}$ values were obtained, the samples were then vacuum filtered through a Buchner funnel using Whatman 40 filter paper and $\mathrm{pH}$ and $\mathrm{EC}$ were measured in the vacuumed extract. All extractions were preserved by refrigeration $\left(5^{\circ} \mathrm{C}\right)$ and the addition of $0.05 \mathrm{~mL}$ phenolmercuric acetate saturated solution until the completion of the study. Samples were then analyzed for $\mathrm{NO}_{3}^{-}, \mathrm{NH}_{4}^{+}$, and $\mathrm{P}$ photometrically (Cataldo et al, 1975; Chaney and Marbach, 1962; Murphy and Riley, 1962) and for $\mathrm{K}, \mathrm{Ca}$, and $\mathrm{Mg}$ using atomic absorption spectrophotemetry (Christian and Feldman, 1970).

The study was a split plot design with a 2 $\times 3 \times 2 \times 2$-factorial treatment combination. Two years served as the main plots, three nutrient levels, two extraction times, and two extraction methods were the subplots. There were five replications per treatment. Analysis of variance was obtained using procedure general linear models $(\alpha=0.01)$ and the nutritional values were regressed and calibration
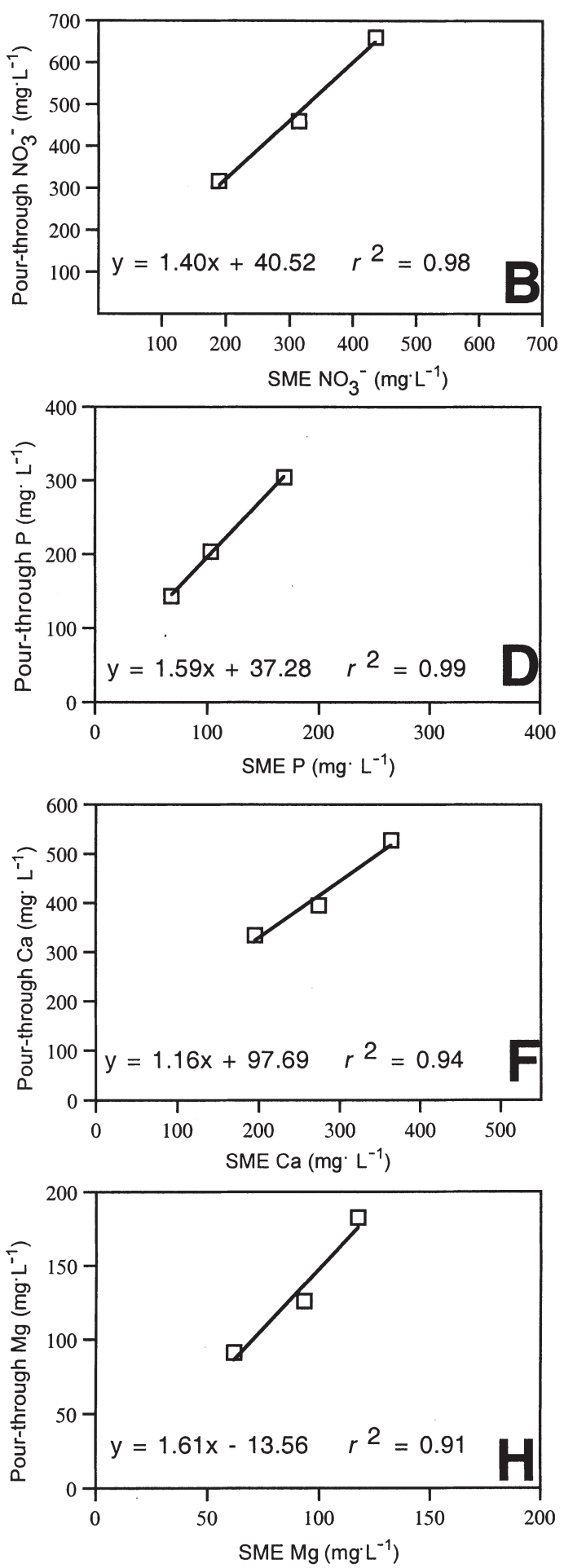

equations developed using PROC REG (SAS Institute, Cary, N.C.).

\section{Results and Discussion}

The substrate $\mathrm{pH}$ did not differ between years or extraction procedures (data not presented). The lack of differences between years suggests that pour-through and SME are reliable, consistent methods for obtaining substrate $\mathrm{pH}$. Surprisingly, there were no differences among extraction procedures (pourthrough, SME slurry, and SME vacuum extract) for pH. Yeager et al. (1983) noted that $\mathrm{pH}$ values for pour-through and SME (suctioned) were similar.

However, Lang (1996) noted that differences $(0.1$ to $0.5 \mathrm{pH}$ units) are commonly obtained between SME $\mathrm{pH}$ values when they are taken from a slurry or vacuum extracted sample. These differences are attributed to partial pressure concentrations of $\mathrm{CO}_{2}$ in the extract versus the atmosphere (Van Leirop, 1990). Evidently, our samples were allowed adequate time to equilibrate with atmospheric $\mathrm{CO}_{2}$ after vacuum extraction to allow the $\mathrm{pH}$ values to return to the initial $\mathrm{pH}$ values prior to vacuum extraction.

As the fertilizer rate increased $(200,300$, or 400

Fig. 1. Calibration curves and equations for comparison of pour-through and SME nutrient values for Euphorbia pulcherrima 'Freedom Red' for (A) $\mathrm{EC},(\mathbf{B}), \mathrm{NO}_{3}^{-},(\mathbf{C})$ $\mathrm{P}$-year 1, (D) $\mathrm{P}$-year 2, (E) $\mathrm{K},(\mathbf{F}) \mathrm{Ca}$-year 1, (G) $\mathrm{Ca}-$ year 2, (H) Mg. 
Table 1. Inverse calibration equations for pourthrough and SME comparisons. Pour-through extraction values are represented as the independent variable $(\mathrm{x})$ and SME values are represented as the dependent variable $(\mathrm{y})$.

\begin{tabular}{llc}
\hline $\begin{array}{l}\text { Nutritional } \\
\text { parameter }\end{array}$ & Regression equation & Adjusted $r^{2}$ \\
\hline $\mathrm{EC}$ & $\mathrm{Y}=0.74 \mathrm{x}-0.05$ & 0.98 \\
$\mathrm{NO}^{-}$ & $\mathrm{Y}=0.71 \mathrm{x}-25.13$ & 0.98 \\
$\mathrm{P}^{\mathrm{z}}$ & $\mathrm{Y}=0.69 \mathrm{x}-1.74$ & 0.97 \\
$\mathrm{P}^{\mathrm{x}}$ & $\mathrm{Y}=0.63 \mathrm{x}-23.39$ & 0.99 \\
$\mathrm{~K}$ & $\mathrm{Y}=0.70 \mathrm{x}-4.66$ & 0.99 \\
$\mathrm{Ca}^{\mathrm{z}}$ & $\mathrm{Y}=0.84 \mathrm{x}-73.43$ & 0.94 \\
$\mathrm{Ca}^{\mathrm{x}}$ & $\mathrm{Y}=0.62 \mathrm{x}+1.55$ & 0.97 \\
$\mathrm{Mg}$ & $\mathrm{Y}=0.59 \mathrm{x}+12.17$ & 0.91 \\
\hline${ }^{ } \mathrm{Equation}$ is based on values obtained in year 1.
\end{tabular}
${ }^{\mathrm{x}}$ Equation is based on values obtained in year 2 .

$\left.\mathrm{mg} \cdot \mathrm{L}^{-1}\right)$, the $\mathrm{pH}$ decreased $(6.12,5.95$, and 5.69, respectively). This $\mathrm{pH}$ decrease likely occurred due to the increased ammonium $\left(\mathrm{NH}_{4}^{+}\right)$content of the fertigation solution; indicating that the uptake of $\mathrm{NH}_{4}^{+}$from the fertilizer, which acidifies the root environment (Marschner et al., 1991), was high enough to counteract the basicity effects of the high nitrate fertilizer formulation $(155 \mathrm{~kg}$ of calcium carbonate $\left[\mathrm{CaCO}_{3}\right]$ equivalent) (The Scotts Co., personal communication).

Sampling date affected $\mathrm{pH}$ such that the substrate $\mathrm{pH}$ increased from week 6 to week 9 (5.80 to 6.17 , respectively) presumably due to build up of basic residues, such as hydroxide ions $\left(\mathrm{OH}^{-}\right)$from $\mathrm{NO}_{3}^{-}$uptake (Raven, 1986) and carbonates $\left(\mathrm{HCO}_{3}^{-}\right.$and $\left.\mathrm{CO}_{3}{ }^{2-}\right)$. As noted above, the fertilizer formulation used generally produces basic residues, which increases the substrate $\mathrm{pH}$.

Electrical conductivity (EC) was not affected by year (data not presented). The lack of differences between years suggests that pour-through and SME are reliable, consistent methods for obtaining substrate EC.

The substrate EC was affected by extraction method. Pour-through EC values (3.54 $\mathrm{mS} \cdot \mathrm{cm}^{-1}$ ) were higher than the SME EC values $\left(2.56 \mathrm{mS} \cdot \mathrm{cm}^{-1}\right)$. Pour-through EC values are generally higher due to less dilution compared to SME EC values (Yeager et al., 1983; Wright et al., 1990). The EC values between pourthrough and SME extractions were compared and a calibration curve was developed to predict values (Fig. 1A). Table 1 lists an inverse of the calibration equation so that SME values can be predicted based on pour-through values. This inversion is necessary because laboratories will likely obtain pour-through nutrient values and want to predict the SME value. The predicted SME values can then be compared to established standard values.

Electrical conductivity (EC) was affected by fertilizer rate. Increasing fertility rates $\left(200,300\right.$, or $\left.400 \mathrm{mg} \cdot \mathrm{L}^{-1}\right)$ increased EC values $\left(2.09,2.99\right.$, and $4.07 \mathrm{mS} \cdot \mathrm{cm}^{-1}$, respectively). Similar trends have been noted by Yelanich and Biernbaum (1993) for SME and Wright et al. (1990) for pour-through.

The EC was not affected by sampling date (data not presented). During weeks 6 and 9 of production ( 0 representing potting day of rooted cuttings), plants are in a state of rapid vegetative growth (Whipker and Hammer, 1997). The lack of differences between sampling dates may be due to the plants actively consuming a majority of the supplied nutrients.

Similar to $\mathrm{EC}, \mathrm{NO}_{3}{ }^{-}$values were not affected by year (data not presented), but were affected by extraction method. As with EC, pour-through $\mathrm{NO}^{-}$values $\left(478.8 \mathrm{mg} \cdot \mathrm{L}^{-1}\right)$ were higher than $\mathrm{SME} \mathrm{NO}_{3}{ }^{-}$values $\left(313.2 \mathrm{mg} \cdot \mathrm{L}^{-1}\right)$. The $\mathrm{NO}_{3}{ }^{-}$values of pour-through and SME extractions were compared and a calibration curve and inverse calibration equation were developed to predict values (Fig. 1B and Table 1 , respectively).

Substrate $\mathrm{NO}_{3}^{-}$values increased with increasing fertilizer rates. As the fertilizer rate increased $\left(200,300\right.$, or $\left.400 \mathrm{mg} \cdot \mathrm{L}^{-1} \mathrm{~N}\right)$, so did the $\mathrm{NO}_{3}{ }^{-}$content of the substrate $(253.0,387.1$, and $547.9 \mathrm{mg} \cdot \mathrm{L}^{-1}$, respectively). The $\mathrm{NO}_{3}{ }^{-}$and EC components behave similarly as $\mathrm{EC}$ is measuring the total concentration of dissolved salts and $\mathrm{NO}_{3}^{-}$is being supplied in the largest quantity. As with $\mathrm{EC}, \mathrm{NO}_{3}^{-}$substrate content was not affected by sampling date. This is attributed to the poinsettias being in a state of rapid vegetative growth and consuming the same amount of $\mathrm{NO}_{3}{ }^{-}$(relatively) during the 3 -week interval (Whipker and Hammer, 1997).

Ammonium $\left(\mathrm{NH}_{4}^{+}\right)$values were not affected by the variables in this study (data not presented). The fertilizer formulation used contained only $1.1 \%$ ammoniacal or urea derived nitrogen $(\mathrm{N})$. The plant likely readily consumed the small amount of $\mathrm{NH}_{4}^{+}$provided. Therefore, only minute amounts of $\mathrm{NH}_{4}^{+}$were detected.

A year $\times$ week interaction affected phosphorus $(\mathrm{P})$ substrate values (Table 2). Phosphorus values in year 1 were much lower than in year 2. Phosphorus also decreased from week 6 to 9 in both years. Warncke and Krauskopf (1983) noted that 6 to $9 \mathrm{mg} \cdot \mathrm{L}^{-1}$ was sufficient $\mathrm{P}$ for proper plant growth and development. In our study, plants were supplied 13.5 to 27.0 $\mathrm{mg} \cdot \mathrm{L}^{-1} \mathrm{P}$ at each irrigation. The decrease from week 6 to 9 is likely due to increased P uptake from the substrate to support the larger plant mass and growth requirements (Whipker and Hammer, 1997).

The variation in $\mathrm{P}$ values between years was attributed to the starter charge variation in the commercial mix. Analysis conducted on the mix before planting indicated the $\mathrm{P}$ values in year 1 were $16.8 \mathrm{mg} \cdot \mathrm{L}^{-1}$ (SME) versus 54.3 $\mathrm{mg} \cdot \mathrm{L}^{-1}(\mathrm{SME})$ in year 2 . This initial starter charge continued to affect $\mathrm{P}$ substrate values throughout the crop cycle. Argo and Biernbaum (1995) noted that containers irrigated only with tap water maintained near optimal levels of nutrients $42 \mathrm{~d}$ after initial irrigation. Though not likely the major cause of the variation in our study, differences in greenhouse temperatures, irradiance, and humidity could have affected the $P$ values between years.

There was a year $\times$ fertilizer rate interaction that affected $\mathrm{P}$ substrate values (Table 3 ). As noted above, the $\mathrm{P}$ content in the starter charge varied between years such that year $1 \mathrm{P}$ substrate values were lower than year 2. Increasing fertilizer rates increase $P$ substrate values; albeit, year 1 had much lower P substrate values than year 2 .
Similar to $\mathrm{EC}$ and $\mathrm{NO}_{3}{ }^{-}$values, $\mathrm{P}$ values were affected by extraction method. Pourthrough $\mathrm{P}$ values $\left(118.4 \mathrm{mg} \cdot \mathrm{L}^{-1}\right)$ were higher than SMEP values $\left(62.6 \mathrm{mg} \cdot \mathrm{L}^{-1}\right)$. The P values of pour-through and SME were compared and calibration curves and inverse calibration equations were developed to predict values (Fig. $1 \mathrm{C}$ and $\mathrm{D}$ and Table 1, respectively). Table 1 lists an inverse of the calibration equations so that SME values could be predicted based on pour-through values.

Potassium extraction values were similar between years (data not presented). However, extraction method affected K values. Like EC, $\mathrm{NO}_{3}{ }^{-}$, and $\mathrm{P}$, pour-through $\mathrm{K}$ values $(336.8$

Table 2. Two-way interactions affecting P nutrient extraction values. Means are an average of 5 replications per treatment.

\begin{tabular}{|c|c|c|}
\hline Year & Week & $\begin{array}{c}\mathrm{P} \\
\left(\mathrm{mg} \cdot \mathrm{L}^{-1}\right)\end{array}$ \\
\hline \multirow[t]{2}{*}{$\overline{1}$} & 6 & 15.80 \\
\hline & 9 & 15.51 \\
\hline \multirow[t]{2}{*}{2} & 6 & 189.01 \\
\hline & 9 & 141.67 \\
\hline \multicolumn{3}{|c|}{ Interaction } \\
\hline & & 0.0004 \\
\hline
\end{tabular}

Table 3. Two-way interactions affecting Pextraction values. Means are an average of five replications per treatment.

\begin{tabular}{lcc}
\hline Year & $\begin{array}{c}\text { Rate } \\
\left(\mathrm{mg} \cdot \mathrm{L}^{-1}\right)\end{array}$ & $\begin{array}{c}\mathrm{P} \\
\left(\mathrm{mg} \cdot \mathrm{L}^{-1}\right)\end{array}$ \\
\hline 1 & 200 & 9.11 \\
& 300 & 15.49 \\
& 400 & 22.37 \\
2 & 200 & 105.99 \\
& 300 & 153.50 \\
& 400 & 236.52 \\
Interaction & & \\
Year $\times$ rate & & 0.0001 \\
\hline \multicolumn{2}{c}{}
\end{tabular}

Table 4. Two-way interactions affecting $\mathrm{Mg}$ extraction values. Means are an average of five replications per treatment.

\begin{tabular}{lcc}
\hline Extraction & $\begin{array}{c}\text { Rate } \\
\left(\mathrm{mg} \cdot \mathrm{L}^{-1}\right)\end{array}$ & $\begin{array}{c}\mathrm{Mg} \\
\left(\mathrm{mg} \cdot \mathrm{L}^{-1}\right)\end{array}$ \\
\hline Pour-through & 200 & 91.15 \\
& 300 & 125.55 \\
SME & 400 & 182.25 \\
& 200 & 61.90 \\
& 300 & 93.30 \\
& 400 & 117.50
\end{tabular}

Interaction

Extraction $\times$ rate

0.0045

Table 5. Recommended pour-through substrate value ranges transformed from $\mathrm{SME}^{\mathrm{z}}$ substrate values.

\begin{tabular}{lcc}
\hline $\begin{array}{l}\text { Nutritional } \\
\text { parameter }\end{array}$ & Pour-through & SME \\
\hline $\mathrm{pH}$ & $5.6-6.0$ & $5.6-6.0$ \\
$\mathrm{EC}\left(\mathrm{mS} \cdot \mathrm{cm}^{-1}\right)$ & $2.8-4.8$ & $2.0-3.5$ \\
$\mathrm{NO}_{3}\left(\mathrm{mg} \cdot \mathrm{L}^{-1}\right)$ & $180-320$ & $100-199$ \\
$\mathrm{P}^{\mathrm{x}}\left(\mathrm{mg} \cdot \mathrm{L}^{-1}\right)$ & $11-16$ & $6-9$ \\
$\mathrm{~K}\left(\mathrm{mg} \cdot \mathrm{L}^{-1}\right)$ & $220-360$ & $150-249$ \\
$\mathrm{Ca}^{\mathrm{w}}\left(\mathrm{mg} \cdot \mathrm{L}^{-1}\right)$ & $330+$ & $200+$ \\
$\mathrm{Mg}\left(\mathrm{mg} \cdot \mathrm{L}^{-1}\right)$ & $100+$ & $70+$ \\
\hline
\end{tabular}

${ }^{z}$ Values adapted from Warncke and Krauskopf, 1983.

${ }^{\mathrm{y}} \mathrm{pH}$ values are equivalent for both extracts.

${ }^{x}$ Values based on year 1 data.

${ }^{\text {w}}$ Values based on year 1 data. 
$\left.\mathrm{mg} \cdot \mathrm{L}^{-1}\right)$ were higher than SME K values (232.2 $\left.\mathrm{mg} \cdot \mathrm{L}^{-1}\right)$. A calibration curve and an inverse calibration equation were developed to predict values (Fig. 1E and Table 1).

Potassium concentrations increased with increasing fertilizer rates. Fertilizer rates of 200,300 , or $400 \mathrm{mg} \cdot \mathrm{L}^{-1} \mathrm{~N}$ produced substrate $\mathrm{K}$ values of $178.5,280.4$, and $394.6 \mathrm{mg} \cdot \mathrm{L}^{-1}$, respectively. Similar trends have been noted by Wright et al. (1990) for pour-through extractions.

As with $\mathrm{EC}$ and $\mathrm{NO}_{3}{ }^{-}$values, $\mathrm{K}$ substrate values were not affected by sampling date (data not presented). This is attributed to the poinsettias being in a state of rapid vegetative growth and consuming the same amount of $\mathrm{K}$ (relatively) during the 3-week interval (Whipker and Hammer, 1997).

Calcium substrate values varied between year $1\left(348.1 \mathrm{mg} \cdot \mathrm{L}^{-1}\right)$ and year $2\left(140.6 \mathrm{mg} \cdot \mathrm{L}^{-1}\right)$. Similar to $\mathrm{P}$, the initial starter charge provided in the commercial mix caused the variation and temperatures, irradiance, and humidity could have contributed to differences. Analysis conducted on the substrate prior to planting indicated the Ca values in year 1 were 277.0 $\mathrm{mg} \cdot \mathrm{L}^{-1}$ (SME) versus $42.6 \mathrm{mg} \cdot \mathrm{L}^{-1}(\mathrm{SME})$ in year 2 . This initial starter charge continued to affect $\mathrm{Ca}$ concentrations throughout the crop cycle. Argo and Biernbaum (1995) noted that containers irrigated only with tap water maintained near optimal levels of nutrients 42 $\mathrm{d}$ after initial irrigation.

Extraction method affected Ca values. Like $\mathrm{EC}, \mathrm{NO}_{3}^{-}, \mathrm{P}$, and $\mathrm{K}$ values, pour-through $\mathrm{Ca}$ values $\left(295.4 \mathrm{mg} \cdot \mathrm{L}^{-1}\right)$ were higher than $\mathrm{SME}$ Ca values $\left(193.3 \mathrm{mg} \cdot \mathrm{L}^{-1}\right)$ due to lack of dilution of the pour-through extract compared to SME extract (Yeager et al., 1983; Wright et al., 1990). The Ca values of pour-through and SME were compared and calibration curves and an inverse calibration equation were developed to predict values for year 1 and two (Fig. $1 \mathrm{~F}$ and $\mathrm{G}$ and Table 1).

Fertilizer rate affected $\mathrm{Ca}$ concentrations. The $13 \mathrm{~N}-0.88 \mathrm{P}-10.8 \mathrm{~K}$ Cal-Mag fertilizer provides $6 \%$ calcium $\left(12,18\right.$, or $24 \mathrm{mg} \cdot \mathrm{L}^{-1}$ for the $\mathrm{N}$ rates used in this study). Therefore, as fertilizer rates increased $(200,300$, or 400 $\left.\mathrm{mg} \cdot \mathrm{L}^{-1} \mathrm{~N}\right)$, so did the Ca substrate concentration (177.6, 237.4, and $\left.318.1 \mathrm{mg} \cdot \mathrm{L}^{-1}\right)$.

As with $\mathrm{EC}, \mathrm{NO}_{3}^{-}, \mathrm{K}$, and $\mathrm{P}$ values, $\mathrm{Ca}$ substrate values were not affected by sampling date (data not presented). This is attributed to the poinsettias being in a state of rapid vegetative growth and consuming the same amount of Ca (relatively) during the 3-week interval (Whipker and Hammer, 1997).

Magnesium (Mg) extraction values were not affected by year (data not presented). However, an extraction by rate interaction affected $\mathrm{Mg}$ substrate values (Table 4). Similar to EC, $\mathrm{NO}_{3}^{-}, \mathrm{P}, \mathrm{K}$, and $\mathrm{Ca}$ values, $\mathrm{Mg}$ pour-through values were higher than SME Mg values and the values increased with increasing fertilizer rates for both extraction methods. Pour-through $\mathrm{Mg}$ values were higher due to lack of dilution compared to SME Mg values (Yeager et al., 1983; Wright et al., 1990). The Mg values of pour-through and SME were compared and a calibration curve was developed to predict values (Fig. 1H). Table 1 lists an inverse of the calibration equation so that SME values could be predicted based on pour-through values.

As with $\mathrm{EC}, \mathrm{NO}_{3}^{-}, \mathrm{K}, \mathrm{P}$, and Ca values, $\mathrm{Mg}$ substrate values were not affected by sampling date (data not presented). This is attributed to the poinsettias being in a state of rapid vegetative growth and consuming the same amount of $\mathrm{Mg}$ (relatively) during the 3-week interval (Whipker and Hammer, 1997).

\section{Conclusion}

Calibration curves were established for $\mathrm{EC}, \mathrm{NO}_{3}^{-}, \mathrm{P}, \mathrm{K}, \mathrm{Ca}$, and $\mathrm{Mg}$. Due to lack of differences in our study, pour-through $\mathrm{pH}$ versus $\mathrm{SME} \mathrm{pH}_{\text {slurry }}$ and pour-through $\mathrm{pH}$ versus $\mathrm{SME}_{\text {vacuum extract }}$ as well as $\mathrm{NH}_{4}^{+}$calibration curves were not developed.

Differences between years were noted with $\mathrm{P}$ and $\mathrm{Ca}$. This was attributed to the initial starter charge difference in the commercial substrate. For P, year 1 had lower initial concentrations than year 2 . This lower concentration likely allowed $\mathrm{P}$ to bind with more affinity to substrate particles due to a lower ionic strength substrate solution. Since P was bound to particles with more affinity, there was less $P$ freely available to the unadulterated pour-through substrate solution. Therefore, pour-through $\mathrm{P}$ extraction values were not as high, relative to SME values, in year 1 compared to year 2 . The year 1-calibration curve should be used for $\mathrm{P}$ comparisons, as most substrate levels will be $<100 \mathrm{mg} \cdot \mathrm{L}^{-1} \mathrm{P}$. The $\mathrm{P}$ values presented in Table 5 were based on the calibration curve obtained in year 1 .

For $\mathrm{Ca}$, year 1 had higher initial concentrations than year 2. This higher concentration may have satiated the substrate binding sites. Therefore, when the substrate samples were diluted (SME), a greater amount of Ca was able to move into the bulk solution (year 1) than would have if the binding sites were not satiated (year 2). The result was that pourthrough and SMECa values were closer in year 1 than in year 2 . The year 1 calibration curve should be used for Ca comparisons, as most Ca substrate values will generally be higher than $250 \mathrm{mg} \cdot \mathrm{L}^{-1}$. The $\mathrm{Ca}$ values presented in Table 5 were based on the calibration curve obtained in year 1 .

In agreement with Yeager et al. (1983) and Wright et al (1990), a relationship exists among pour-through and SME values. In our study, pour-through nutrient values (excluding $\mathrm{pH}$ and $\mathrm{NH}_{4}^{+}$) were about 1.4 to 1.6 times higher than SME values, except for $\mathrm{Ca}$ (year 1) whose relationship was about 1.2 times higher (Fig. 1A-H). This is similar to Yeager et al. (1983) who reported pour-through values about 1.3, 1.4, and 1.2 times higher than SME values for $\mathrm{N}, \mathrm{P}$, and $\mathrm{K}$, respectively; Yeager also noted that $\mathrm{pH}$ values were similar, which is agreement with our findings. Scoggins et al. (2002) noted comparable findings with the press extraction method, which is similar to pour-through such that an undiluted substrate solution is obtained for analysis, with EC, $\mathrm{NO}_{3}^{-}$, and $\mathrm{P}$ values that were $1.4,1.8$, and 1.7 times higher than SME.
However, we did not find a similar relationship of pour-through and SME values as described by Wright et al. (1990) who noted that pour-through values were nearly double that of SME values. These differences are likely due to variances in testing procedures (water content of the SME) that may have altered nutrient values.

Based on the calibration curves developed in our study and recommended SME values (Warncke and Krauskopf, 1983), recommended pour-through nutrient values for greenhouse substrates have been developed (Table 5). Additionally, calibration curves (Table 1) that allow substrate-testing laboratories to convert pour-through values to SME values and compare those values to established standard values have been presented.

\section{Literature Cited}

Argo, W.R. and J.A. Biernbaum. 1995. Root-medium nutrient levels and irrigation requirements of poinsettias grown in five root media. HortScience 30:535-538.

Burd, J.S. and J.C. Martin. 1923. Water displacement of soils and the soil solution. J. Agr. Sci. 13:265-295.

Cabrera, R.I. 1998. Monitoring chemical properties of container growing media with small soil solution samplers. Sci. Hort. 75:113-119.

Cataldo, D.A., M. Haroon, L.E. Schrader, and V.L. Youngs. 1975. Rapid colormetric determination of nitrate in plant tissue. Comm. Soil Sci. Plant. Anal. 6:71-80.

Cavins, T.J., B.E. Whipker, W.C. Fonteno, and J.L. Gibson. 2000. Establishing a PourThru sampling program. part 1. Ohio Florists' Assn. Bul. 846:1-11.

Chaney, A.L. and E.P. Marbach. 1962. Modified reagents for determination of urea and ammonia. Clinical Chem. 8:130-132.

Christian, G.D. and F.J. Feldman. 1970. Atomic absorption spectroscopy: Applications in agriculture, biology, and medicine. Wiley Interscience, New York.

Compton, A.J. and P.V. Nelson. 1997. Timing is crucial for plug seedling substrate testing. HortTechnology 7:63-68.

Dole, J.M. and H.F. Wilkins. 1999. Nutrition, p. 57-78. In: Floriculture: Principles and species. Prentice Hall, Upper Saddle River, N.J.

Handreck, K.A. 1994. Pour-through extracts of potting media: Anomalous results for $\mathrm{pH}$. Commun. Soil Sci. Plant Anal. 25:2081-2088.

Hipp, B.W., D.L. Morgan, and D. Hooks. 1979. A comparison of techniques for monitoring $\mathrm{pH}$ of growing medium. Commun. Soil Sci. Plant Anal. 10:1233-1238.

Jarrell, W.M., R.A. Shepherd, and R.L. Branson. 1979. Leachate and soil $\mathrm{pH}$ changes in potting mixes treated with $\mathrm{NaHCO}_{3}$ and $\mathrm{KHCO}_{3}$ solutions. J. Amer. Soc. Hort. Sci. 104:831-834.

Lang, H.J. 1996. Growing media, testing and interpretation, p. 123-139. In: In: D.W. Reed (ed.) Water, media, and nutrition for greenhouse crops. Ball Publishing, Batavia, Ill.

Lang, H.J. and G.C. Elliot. 1991. Influence of ammonium: nitrate ratio and nitrogen concentration of nitrification activity in soilless potting media. J. Amer. Soc. Hort. Sci. 116:642-645.

Marschner, H., M. Haussling, and E. George. 1991. Ammonium and nitrate uptake rates and rhizosphere-pH in non-mycorrhizal roots of Norway spruce (Picea abies (L.) Karst.). Trees. 5:14-21. 
Murphy, J. and J.P. Riley. 1962. A modified solution method for the determination of phosphate in natural waters. Anal. Chim. Acta. 27:31-36.

Raven, J.A. 1986. Biochemical disposal of excess $\mathrm{H}^{+}$ in growing plants. New Phytol. 104:175-206.

Ruter, J.M. 1992. Leachate nutrient content and growth of two hollies as influenced by controlled release fertilizers. J. Environ. Hort. 10: $162-166$.

Scoggins, H.L., D.A. Bailey, and P.V. Nelson. 2002. Efficacy of the press extraction method for bedding plant plug nutrient monitoring. HortScience 37:108-112.

U.S. Department of Agriculture- National Agriculture Statistics Service. 2003. Sp Cr 6-1 (03).

Van Leirop, W. 1990. Soil pH and lime requirement determination, p. 73-126. In: Soil testing and plant analysis. no. 3. Soil Sci. Soc. Amer.,
Madison, Wis.

Warncke, D. 1998. Greenhouse root media, p. 61-64. In: Recommended chemical soil test procedures for the north central region. Mo. Agr. Expt. Sta. SB1001.

Warncke, D.D. and D.M. Krauskopf. 1983. Greenhouse growth media: Testing and nutritional guidelines. Mich. State Univ. Coop. Ext. Serv. Bul. E-1736.

Whipker, B.E. and P.A. Hammer. 1997. Nutrient uptake in poinsettias during different stages of physiological development. J. Amer. Soc. Hort. Sci. 122:565-573.

Wright, R.D. 1986. The pour-through nutrient extraction procedure. HortScience 21:227-229.

Wright, R.D., K.L. Grueber, and C. Leda. 1990. Medium nutrient extraction with the pour-through and saturated medium extract procedure for poinsettia. HortScience 25:658-660.

Yeager, T.H. and R.D. Wright. 1981. Response of Ilex crenata Thunb. cv. Helleri to superphosphate-incorporated pine bark. HortScience 16:202-203.

Yeager, T.H. and R.D. Wright. 1982. Phosphorous requirement of Ilex crenata Thunb. cv. Helleri grown in a pine bark medium. J. Amer. Soc. Hort. Sci. 107:558-562.

Yeager, T.H., R.D. Wright, and S.J. Donohue. 1983. Comparison of pour-through and saturated pine bark extract N, P, K, and pH levels. J. Amer. Soc. Hort. Sci. 108:112-114.

Yelanich, M.V. and J.A. Biernbaum. 1993. Root medium nutrient concentration and growth of poinsettia at three fertilization concentrations and four leaching fractions. J. Amer. Soc. Hort. Sci. 118:771-776. 